DOI: 10.20472/IAC.2019.052.058

\author{
REJINA M. SELVAM \\ UNIVERSITAT INTERNACIONAL DE CATALUNYA, Spain
}

CATARINA LELIS

University of West London, United Kingdom

\title{
TOWARDS CO-CREATION:EXPLORING PROSPECTS OF EMPLOYEE BRAND KNOWLEDGE IN INTERNAL BRANDING
}

\begin{abstract}
:
The success of an organization to communicate the brand promise is premised by the internal branding procedure and the contribution of employees in the creation of branding. The present study provides the importance that employees have in providing value to the organization from the perspective of the holistic brand knowledge pyramid which includes, brand citizenship, brand commitment, and belonging. In -depth interviews were conducted from an $\mathrm{H}$. E institute to understand employee involvement in internal branding and the related organizational requirements from a knowledge based management environment. The results provide insight into the strength of employee participation in the co-creation of brand and the organizational requirements for stimulating its human capital to live the brand in its environment.
\end{abstract}

\section{Keywords:}

Internal Branding, Brand commitment, Internal Communication, Brand knowledge, Brand co-creation

JEL Classification: J24, D23, 123 